\title{
Performance and Emission Characteristics of Homogeneous Charge Compression Ignition Engine with Different Bio Diesel Fuels
}

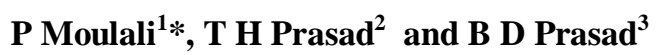 \\ ${ }^{* 1}$ Research Scholar, Department of ME, JNTUA, Ananthapuramu-515002, AP, India. \\ ${ }^{2}$ Department of ME, Sree Vidyanikethan Engineering College, Tirupati-517102, AP, India. \\ ${ }^{3}$ Department of ME, JNTUA College of engineering, Ananthapuramu-515002,AP, India \\ *Corresponding author E-mail:moulalip20@gmail.com
}

\begin{abstract}
In this paper the emission characteristics and performance of various bio diesel fuels (Tyre pyrolysis oil (TPO), Micro algae oil and Pig animal fat oil) were experimented. A single cylinder, water cooled diesel engine was modified in to homogeneous charge compression ignition engine (HCCI) with adopted port fuel injection (PFI) technique. The effects of air fuel ratio, intake temperature, injection pressure and EGR rate exhaust emissions were explained in a broad manner. The analysis of the exhaust emissions are integrated to oxides of Nitrogen (NOx), Carbon Monoxide (CO), unburned hydro carbons (UHC), smoke and soot. The performance analysis was also included on specific fuel consumption and break thermal efficiency. The basic requirements for HCCI engine is the homogeneous mixture preparation of air and fuel. This mixture formation was done by adopting port fuel injection technique and external devices were also used for bio diesel vaporization and mixture preparation. The combustion processes were measured with different EGR system. The experimental results of different bio diesel fuels with $\mathrm{HCCI}$ engine mode were recorded and evaluated. A small increase in CO and $\mathrm{HC}$ emissions were observed with increasing bio diesel content due to slow evaporation rate of bio diesel. A significant reduction in NOx emission was also observed with respect to difference in bio diesel blends. Micro algae oil was found more stable compared with other bio diesel fuels due to the property of fuel vaporization and low heat releasing.
\end{abstract}

Keywords: Performance characteristics; emission characteristics; homogeneous charge compression ignition engine; micro algae oil; tyre pyrolysis oil; pig animal fat oil.

\section{Introduction}

Now a day's many automobile industries are looking for alternative technology in Internal Combustion (IC) Engine. A promising alternative is Homogeneous Charge Compression Ignition (HCCI) engines as it produces low emissions of NOx and particulate Matter (PM). In an IC engine, HCCI combustion can be achieved by premixing the air-fuel mixture and compressing it until the temperature is high enough for auto ignition (just like in the CI engine). The main challenges of HCCI engine are to control the combustion and to prepare the homogeneous mixture. In HCCI engine, a homogeneous charge is prepared by port fuel injector technique that injects the fuel on the inlet air stream to form premixed charge. The external mixture formation has the major problem of higher UHC emissions.

In 1997, Gray and Ryan used an electronic port fuel injector mounted $15 \mathrm{~mm}$ diameter upstream of the inlet valve; this was used for injecting fuel into the intake air for HCCI mode engine operation $^{[1]}$. In 2000, Christensen and Johansson has been noted that with the variation in the equivalence ratio the $\mathrm{CO}$ and $\mathrm{HC}$ emissions also increases, as the combustion becomes highly incomplete due to lack of time for fuel mixing with air or by lack of oxygen $^{[2]}$. In 2002, Zhao H, Li J, Ma T, Ladommatos N conducted experiment on the 4 stroke multi cylinder gasoline engine with the
CAI combustion and analysed the Performance and analysis ${ }^{[3]}$. In 2003, Tsolakis et al., to performed on The HCCI engine has at

tracted a lot of attention in the combustion process for its low NOx emissions, low fuel consumption and high thermal efficiency characteristics $^{[4]}$. In 2005, Odaka et al., was used earliest premixed/ direct injected system for HCCI operation. In this system, most of the fuel was injected into the intake manifold to form a homogeneous charge. The premixed charge was injected with small amount of fuel directly to the cylinder. The system achieved a reduction in both NOx and smoke emissions better than conventional diesel engine.

The major problem of modifying conventional diesel engine to HCCI mode engine is the controlling of the combustion and possible high emission of $\mathrm{CO}$ and $\mathrm{HC}^{[5]}$. In 2007, Chisti, Y al., In Bio diesel fuels consider an alternative fuels; bio diesel extracted from the crops, they concluded that the waste cooking oil and animal fat oil cannot realistically satisfy even a small fraction of the existing demand for transport fuels ${ }^{[6]}$ and L. Xingcai et al., was conducted the experiment on HCCI engine and studded on the cycle-by-cycle variations of combustion by using primary reference fuels and their mixtures ${ }^{[7,10]}$. In 2008, Himabindu et al has performed on the HCCI combustion of diesel fuel with external mixture formation technique revealed that $\mathrm{NOx}$ emissions reduced by $45-95 \%$ with $0-30 \%$ EGR at $75 \%$ load compared to conven- 
tional diesel combustion. In similar fashion, the smoke emissions reduced by $40-83 \%$ for the same load $(75 \%)$ with $0-30 \%$ EGR compared to that of conventional diesel operation. Furthermore the recent studies on HCCI combustion characteristics using premixed charge disclosed significant reductions in both NOx and smoke emissions [8, 11, and 17]. In 2010, Ramesh, S et al., and 2012 singh AP were used HCCI engine and studied the performance of the engine using various bio diesel fuels [9, 12-14]. In 2015 A.Avinash, et al., conducted experiment on Lean homogeneous combustion using external mixture formation technique used as an E-diesel fuel and performed emission analysis [15]. In 2017, Akhilendra pratap singh Partially used low volatility fuel and performed Homogeneous charge compression Ignition Engine ${ }^{[16]}$ The bio diesel produced from vegetable oil and animal fat using alcohol such as methanal, ethanol or butanol along with catalyst. The researcher focused on the production of bio diesel by using high oil content crops. Selected bio diesel micro algae oil is unicellular, photosynthetic micro organisms. They also grow extremely fast. Major problems in homogeneous mixture preparation: it required high intake temperature of air for external mixture preparation, this paper proposed preparation of the homogeneous mixture with the external mixture formation to control the combustion and ignition by using the ECU. The air heaters were used for heating the intake air based on the performance of the fuels. This research investigated different bio diesel fuels like TPO, Micro algae oil and Pig animal fat oil at constant speed of 1500 $\mathrm{rpm}$. Exhaust gas recirculation was used up to $30 \%$ to reduce the $\mathrm{HC}$ and $\mathrm{CO}$ of $\mathrm{HCCI}$ mode engine.

\section{Experimental setup}

The single cylinder, four strokes, water cooled, Direct Injection engine with eddy current load engine to modify into HCCI mode engine. It is adopted with external mixture formation technique as shown in Fig1. The engine specification details are listed in the Table 1 . The amount for fuel injection and injection timing were controlled by ECU depending on engine speed and load. Eddy current dynamometer was controlled manually and the load applied was displayed in the digital meter on control panel. Experiment conducted at a speed of $1500 \mathrm{rpm}$, the conditions of engine running, speed and temperature (inlet air temperature, outlet air temperature, and combustion temperature) were displayed in the digital meter. The quantity of exhaust gases form the exhaust manifold was maintained and the fresh air temperature was measured through the temperature sensors and connected to the control unit. Exhaust gases were controlled by manual control valve. Increase in EGR increases inlet temperature and slows down the combustion processes. It resulted decrease in peak pressure and heat release and therefore longer combustion rate was achieved and efficiency increased along with EGR.

The transesterification process was conducted to extract the bio diesel fuels. The extracted bio diesel fuels were blended with the pure diesel fuel in the ratio of $20 \%$ bio diesel and $80 \%$ diesel (B20) and 40\% bio diesel fuel and $60 \%$ Diesel fuel (B40). The properties of the bio diesel fuel were maintained as per the ASTM standard.

The properties of the diesel fuel, bio diesel fuel are listed in the Table 2, properties of the blended bio diesel fuels for B20 and B40 are presented in the Table 3,4 and 5. The better combustion was achieved by Exhaust gas recirculation process. Before to the manifold inlet, fresh air was mixed with $10 \%$ of EGR. The experiment was conducted for different blends of the bio diesel fuels at constant operation of EGR with variation in the inlet temperature based on the performance of the bio diesel fuels. The performance and emission characteristics are compared between the unmodified direct injection diesel engine and modified HCCI engine with pure diesel fuels. The optimum operating conditions was also observed for the blended bio diesel fuels. Table 1 shows the exhaust emission ranges of Gas analyser and smoke analyser, it was used to measure the emission of HCCI-mode engine, such as $\mathrm{NOx}, \mathrm{PM}, \mathrm{HC}, \mathrm{CO}_{2}$ and $\mathrm{CO}$. AVL smoke meter measure the exhaust smoke of the engine.

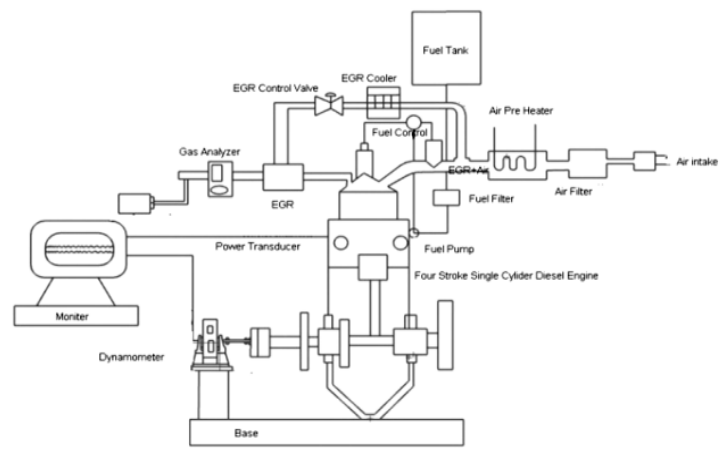

Fig1: Schematic diagram for experimental work

Table 1: Engine

\begin{tabular}{|l|l|l|}
\hline S.No & Specification & Ranges \\
\hline 1 & Make & Kirlosker \\
\hline 2 & Type & 4 S 1 C \\
\hline 3 & Type of cooling & Water-Cooled \\
\hline 4 & Stroke & $110 \mathrm{~mm}$ \\
\hline 5 & Compression ration & $17.5: 1$ \\
\hline 6 & Bore & 87.5 \\
\hline 7 & Rated Speed & $1500 \mathrm{rpm}$ \\
\hline 8 & Rated power & $4 \mathrm{KW}$ \\
\hline 9 & Orifice diameter & $13.6 \mathrm{~mm}$ \\
\hline 10 & Co efficient of discharge & 0.64 \\
\hline 11 & Type of sensors & K-type \\
\hline 12 & Fuel injection pressure & $2.5-3 \mathrm{bars}$ \\
\hline 13 & Fuel injectors & 4 \\
\hline 14 & AVL Di-Gas Analyzer & Nox $-0-500 \mathrm{ppm}$ \\
& & HC- $0-1000 \mathrm{ppm}$ \\
& & CO-0-10\% \\
& & CO2-0-20\% \\
\hline 15 & AVL Smoke meter & $0-100$ \\
\hline 16 & Engine water flow & $1201 \mathrm{ph}$ \\
\hline 17 & Inlet temperature measurement & RTD \\
\hline
\end{tabular}

\begin{tabular}{|c|l|c|c|c|c|}
\hline Table 2: Fuel properties \\
\hline S.No & $\begin{array}{l}\text { Properties of } \\
\text { fuels }\end{array}$ & Diesel & $\begin{array}{c}\text { Micro } \\
\text { algae } \\
\text { oil }\end{array}$ & $\begin{array}{c}\text { Tyre Pyroly- } \\
\text { sis Oil } \\
(\mathrm{TPO})\end{array}$ & $\begin{array}{c}\text { pig } \\
\text { animal } \\
\text { fat oil }\end{array}$ \\
\hline 1 & $\begin{array}{l}\text { Density } \\
\left(\mathrm{Kg} / \mathrm{m}^{3}\right)\end{array}$ & 823 & 868 & 903 & 920 \\
\hline 2 & $\begin{array}{l}\text { Calorific } \\
\text { valve }(\mathrm{MJ} / \mathrm{Kg})\end{array}$ & 42.6 & 40.23 & 39.8 & 38.85 \\
\hline 3 & $\begin{array}{l}\text { Kinematic } \\
\text { viscosity at } \\
40^{\circ} \mathrm{C}\end{array}$ & 3.01 & 4.52 & 3.5 & 3.3 \\
\hline 4 & $\begin{array}{l}\text { Cetane Num- } \\
\text { ber }\end{array}$ & 52 & 47 & 46 & 42 \\
\hline 5 & Flash point ${ }^{\circ} \mathrm{C}$ & 51 & 113 & 46 & 44 \\
\hline 6 & Fire Point ${ }^{\circ} \mathrm{C}$ & 57 & 120 & 52 & 51 \\
\hline 7 & Boiling point & $180-$ & $220-430$ & $100-360$ & $70-360$ \\
\hline
\end{tabular}

Table 3: Main Properties of the Blended Fuels: Micro Algae oil

\begin{tabular}{|c|c|c|}
\hline Properties of Fuels & B20 & B40 \\
\hline Density $\left(\mathrm{Kg} / \mathrm{m}^{3}\right)$ & 837 & 843 \\
\hline Calorific valve $(\mathrm{MJ} / \mathrm{Kg})$ & 44.3 & 43.6 \\
\hline Kinematic viscosity at $40^{\circ} \mathrm{C}$ & 2.67 & 2.93 \\
\hline Cetane Number & 50 & 49 \\
\hline Specific Gravity & 0.837 & 0.843 \\
\hline
\end{tabular}

Table 4: Main Properties of the Blended Fuels: TPO

\begin{tabular}{|l|c|c|}
\hline Properties of Fuels & B20 & B40 \\
\hline Density $\left(\mathrm{Kg} / \mathrm{m}^{3}\right)$ & 887 & 894 \\
\hline
\end{tabular}




\begin{tabular}{|c|c|c|}
\hline Calorific valve $(\mathrm{MJ} / \mathrm{Kg})$ & 37.75 & 35.12 \\
\hline Kinematic viscosity at $40^{\circ} \mathrm{C}$ & 5.6 & 5.82 \\
\hline Specific Gravity & 0.887 & 0.894 \\
\hline
\end{tabular}

Table 5: Main Properties of the Blended Fuels: Animal Fat Oil

\begin{tabular}{|l|l|l|}
\hline Properties of Fuels & B20 & B40 \\
\hline Density $\left(\mathrm{Kg} / \mathrm{m}^{3}\right)$ & 874 & 889 \\
\hline Calorific valve $(\mathrm{MJ} / \mathrm{Kg})$ & 37.68 & 34.92 \\
\hline Kinematic viscosity at $40^{\circ} \mathrm{C}$ & 4.8 & 4.98 \\
\hline Specific Gravity of the fuel & 0.874 & 0.889 \\
\hline
\end{tabular}

\section{Results and discussion}

Single cylinder four stroke water cooled diesel engine was modified in to HCCI engine with port fuel injection system. This research was experimented with different bio diesel fuels likely TPO, micro algae oil, pig animal fat oil. The results were analysed for different operating conditions at the constant speed of $1500 \mathrm{rpm}$. The intake air temperature was selected based on the air- fuel ratio. At higher intake air temperature, richer mixture of fuel-air has advanced ignition timing and rate of pressure rise is also very high, which leads to knocking combustion. To avoid the knocking combustion, engine is operated at leaner mixture thus the IMEP is lower.

\subsection{Break Thermal Efficiency}

As shown in Fig 2 variation of the break thermal efficiency with three different bio diesel fuels on conventional engine and modified HCCI engine with variation of intake temperature based on the performance of the air- fuel ratio were recorded. Bio diesel fuel were blended for the ratio of B20 (diesel fuel $80 \%$ and bio diesel 20\%) and B40 (diesel fuel $60 \%$ and bio diesel 40\%). The increase in the break power resulted further increase in the break thermal efficiency of the fuel. The observed break thermal efficiency of the conventional diesel engine is $34.15 \%$ and HCCI engine running with diesel fuels is $32.13 \%$.

Variation in BTE with the variation of the three different bio diesel fuels with blends B20 and B40 are shown in the Fig 2 and 3 respectively. All the four cases break thermal efficiency of the engine was increased with increase in break power. The BTE is observed all the blends of three different bio diesel fuels and the optimum level was achieved at B20. The BTE among three different bio diesel fuels, the algae oil is more compared to Pig animal fat oil and TPO at B20. Micro algae oil is $15.68 \%, 22.58 \%, 29.1 \%$ and $32.4 \%$ at different load conditions. Similarly the animal fat oil $\mathrm{BTE}$ at B20 is $22.56 \%$ and for TPO at max load conditions reported $22.52 \%$.

Fig 3 shows the performance of three different bio diesel fuels blended with B40. The increase in the break power also increased the BTE, compared with B20 it is slightly decreases, because of viscosity of the fuel is higher than B20. Viscosity increases than BTE decreases, increases blends always decreases the BTE. Break thermal efficiency of algae oil is more than the remaining two different fuels as shown in the Fig 3.

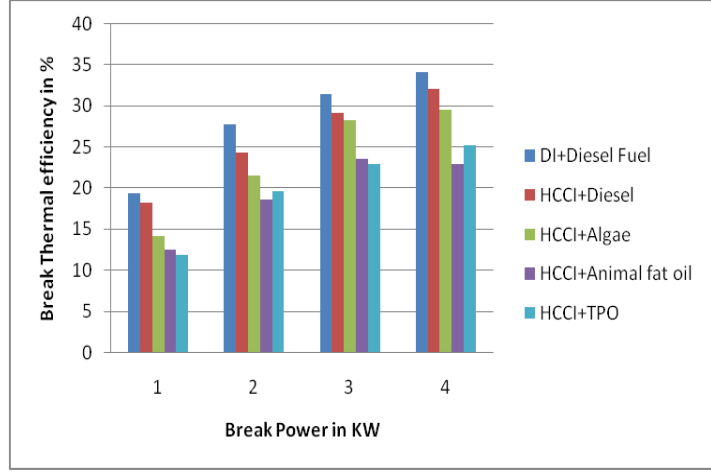

Fig. 2: Break thermal efficiency B20

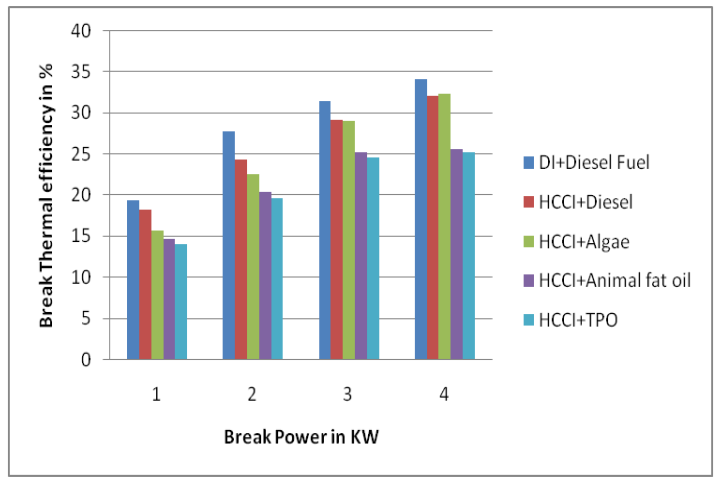

Fig. 3: Break power Vs BTE B40

\subsection{Specific fuel consumption}

In Fig. 4 and 5 shows the variation of the specific fuel consumption with variation of the break power on HCCI engine. In general HCCI engine have been consumed less amount of fuel than the conventional unmodified diesel engine. The Fig. 4 and 5 indicates that the bio diesel fuelled HCCI engine has higher specific fuel consumption compared to diesel fuelled HCCI engine, as the calorific valve of bio diesel fuel is lower than diesel fuels. The Biodiesel blends and it continuously increases with increasing biodiesel content in the test fuel were clearly observed. At higher blend (B40), SFC showed a different behaviour due to relatively dominant EGR than biodiesel content. Inlet temperature also effected the SFC consumption. Inlet temperature increases as the air molecules are extended and reduce the volumetric efficiency of the air. Minimum specific fuel consumption was achieved at part load condition. The experimental results in the graph indicated that among three different fuels the micro algae oil is encountered with less specific fuel consumption than other two fuels, as the calorific value of micro algae oil is more than other diesel fuels.

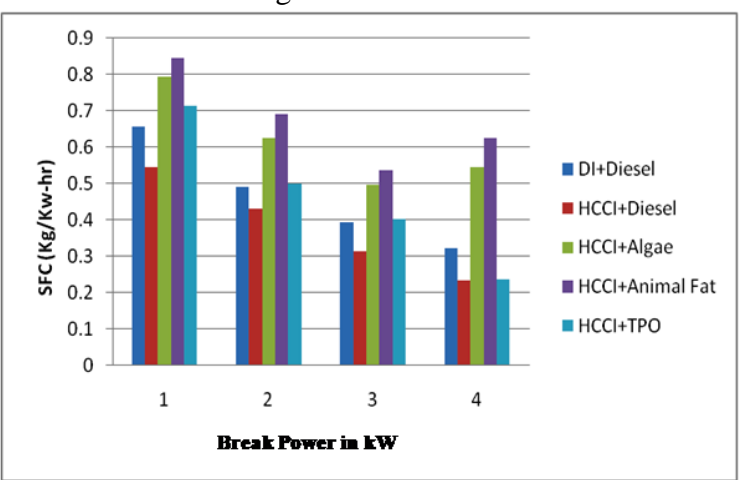

Fig.4: Specific fuel consumption with B20 


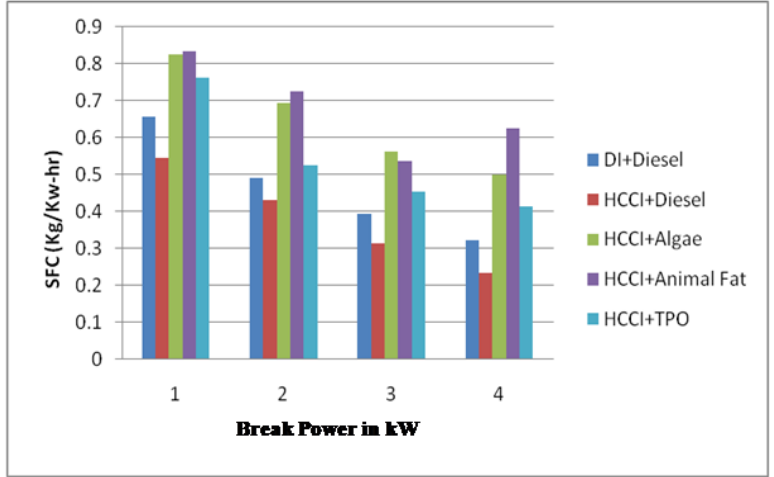

Fig.5: Specific fuel consumption with 40

\subsection{Oxides of Nitrogen}

The main advantage of HCCI engine is to reduce the oxides of the nitrogen. The figure 6 and 7 shows the variation of the oxides of nitrogen for different bio diesel fuels with B20 and B40 blends. The unmodified diesel engine is produced more oxides of nitrogen than HCCI mode engine. In bio diesel fuels the diesel engine produced high amount of oxides of nitrogen because of high cetanenumber. Also it reduced the ignition delay and ignition duration which produced high knocking and combustion temperature. Bio diesel fuels running with the HCCI engine mode produced less amount of NOx because of lean mixture proposition. It is observed from the figure 6 , the oxides of the nitrogen were $200 \mathrm{ppm}, 742$ ppm, $948 \mathrm{ppm}$, and $1098 \mathrm{ppm}$ in the diesel engine reduced to 84 ppm, $233 \mathrm{ppm}, 459 \mathrm{ppm}, 629 \mathrm{ppm}$ at HCCI engine with diesel fuel. At HCCI engine mode the micro algae oil is produced less NOx compared to other fuels. Fig. 6 and 7 shows the oxides of nitrogen; the B20 produced less amount of NOx than B40.

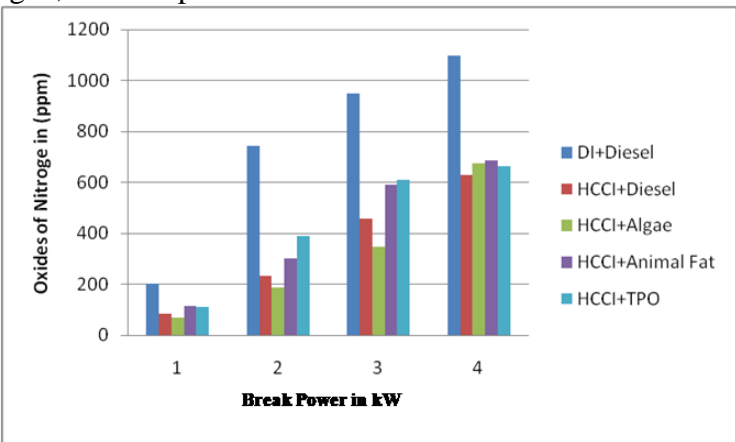

Fig.6: Oxides of nitrogen in B20

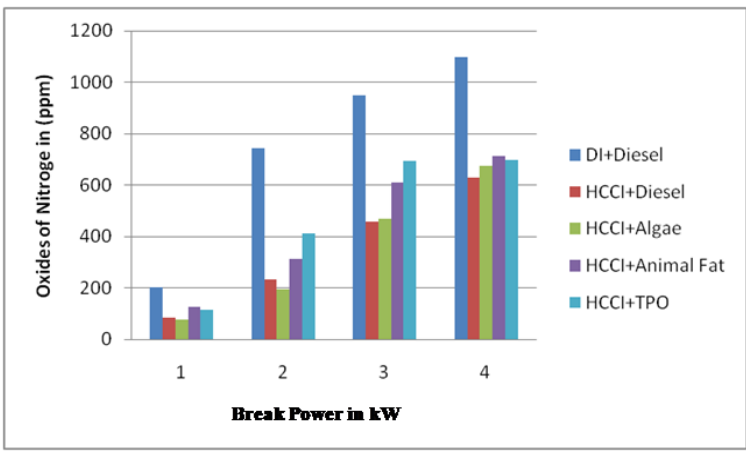

Fig.7: Oxides of nitrogen in B40

\subsection{Carbon Monoxide (CO)}

The emission of carbon monoxide has favoured the incomplete combustion and high temperature. The figure 8 and 9 shows the variation of $\mathrm{CO}$ with different bio diesel fuels with different inlet temperature of unmodified engine and HCCI mode engine. One of the major disadvantages observed on unmodified diesel engine was less $\mathrm{CO}$ than compared to $\mathrm{HCCI}$ Diesel engine because of air fuel mixture created before start of combustion processes in HCCI engine. To prevent the rich mixture in the combustion chamber, fuel was spared in to the entire cylinder to make the lean mixture. The Fig. 9 shows the bio diesel fuel running with the HCCI mode TPO produced less $\mathrm{CO}$ than other bio diesel fuels and also less than the fossil fuel. The reduction of $\mathrm{CO}$ in the emission influences the presence of rich mixture in the combustion chamber. The presence of oxygen is more in bio diesel fuels; engine with bio diesel fuels $\mathrm{CO}$ is converted to carbon monoxide. The Fig. 9 shows that the CO was reduced than other fuels. The blend B20 was optimal because of inside the combustion is prepared in rich mixture.

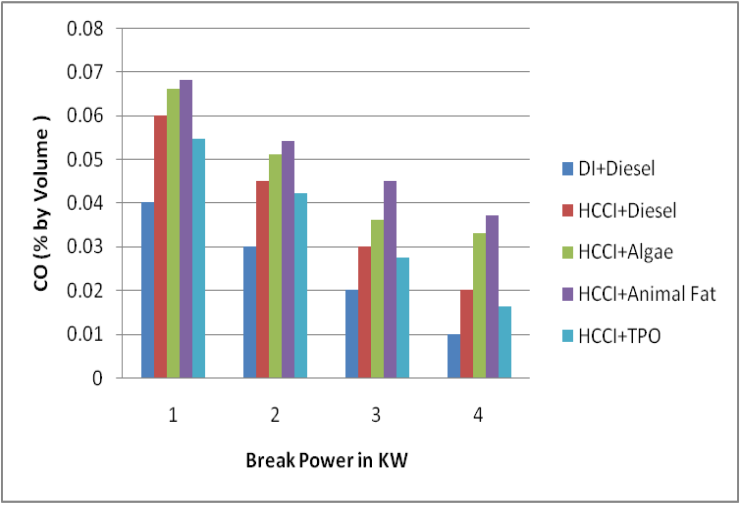

Fig.8: Carbon monoxide in B20

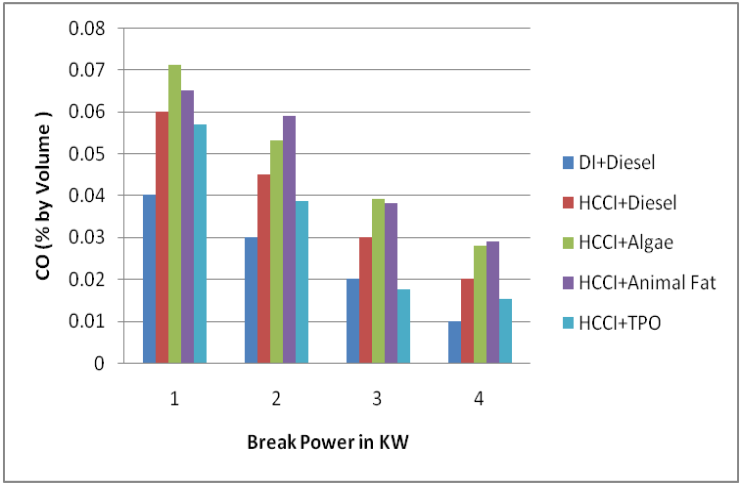

Fig.9: Carbon monoxide in B40

\subsection{Smoke Density}

The variation of the smoke density with the break power is shown in the Fig. 10 and 11. The smoke density produced in the unmodified engine was more than HCCI mode engine. Among three different bio diesel fuels the micro algae oil produced less smoke density because of more oxygen content in micro algae oil induced complete combustion in the engine cylinder. The Fig. 10 represents the smoke densities of different fuels with a blend of B20. The micro algae oil was reported with $8.4 \mathrm{HSU}, 12.6 \mathrm{HSU}, 19.5$ HSU and 26.2 HSU for different load conditions. Similarly the animal fat oil was recorded with 7.6 HSU, 14.5 HSU, 19.6 HSU, 31.2 HSU and TPO was recorded with 9.2 HSU, 17.5 HSU, 22.3 HSU, and 28.7 HSU for different load conditions. The performance of fuel property induced the variation in the temperature; temperature increases/ decreases influenced to decrease the smoke density up to $140{ }^{\circ} \mathrm{C}$ based on fuel property. The Fig. 10 shows the smoke density of the various bio diesels blend. The observed result indicates the smoke density was increased than B20 fuels, as because the viscosity of the fuels increased and therefore inside the combustion attained rich mixture. 


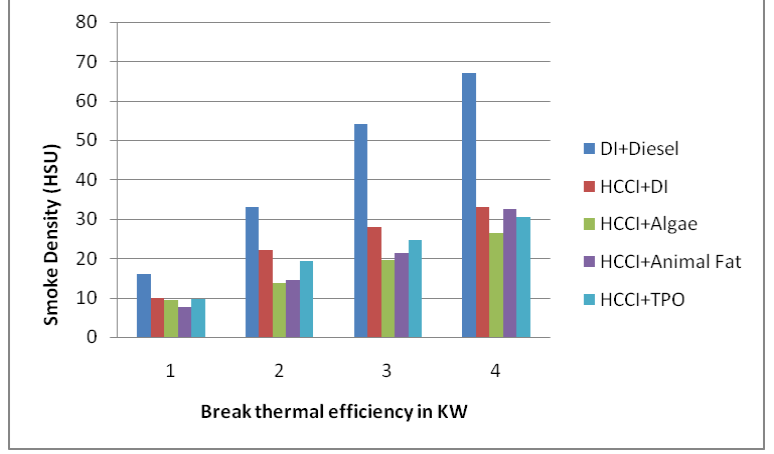

Fig.10: Smoke Density with B20

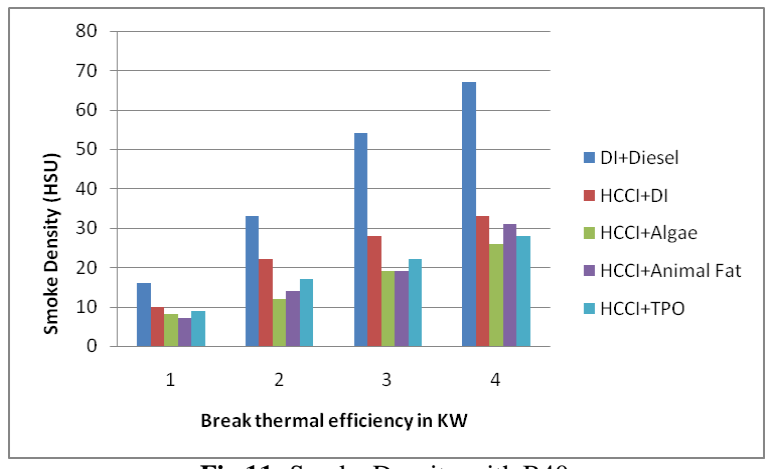

Fig.11: Smoke Density with B40

\subsection{Hydro Carbon (HC)}

Hydro Carbon is having disadvantage in the HCCI engine, because of HCCI engine all the operating condition is lean mixture preparation. Air/ fuel mixture has reduced the combustion temperature and pressure in HCCI engine mode. Low combustion temperature produced high amount of the Hydro carbons as shown in the Fig. 12. The variations of the hydro carbons of different bio diesel fuels with HCCI mode engine, at minimum load condition produced less amount of the $\mathrm{HC}$ at minimum load condition. However, the hydro carbons were increased along with the increase in load. The amount of HC can be controlled in the HCCI engine through recirculation of exhaust gas and increasing the inlet temperature; it causes to increases the combustion temperature to control HC in HCCI engine mode. The Fig. 12 and 13 indicates the variation of $\mathrm{HC}$ of different bio diesel fuels with blends of $20 \%$ and $40 \%$ of the bio diesel fuels. The $40 \%$ of bio diesel fuels were produced less amount of the hydro carbons than the $20 \%$ of the bio diesel fuels by circulating the EGR and inlet air temperature reduced $15 \%$ ppm.

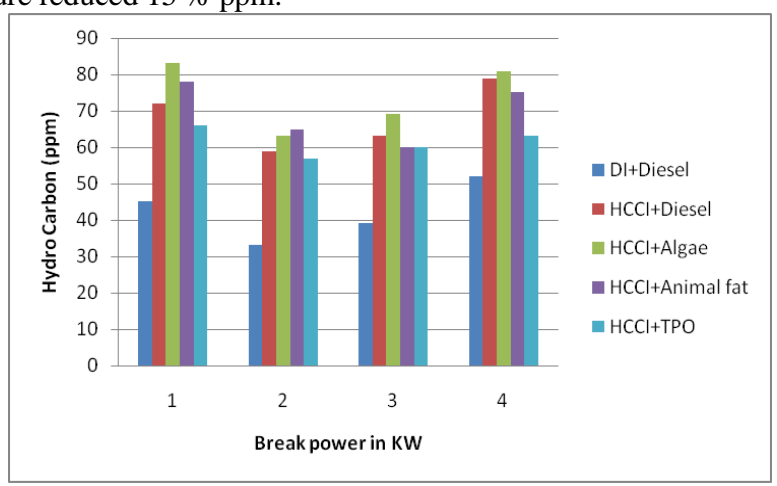

Fig.12: Hydro Carbon with B20

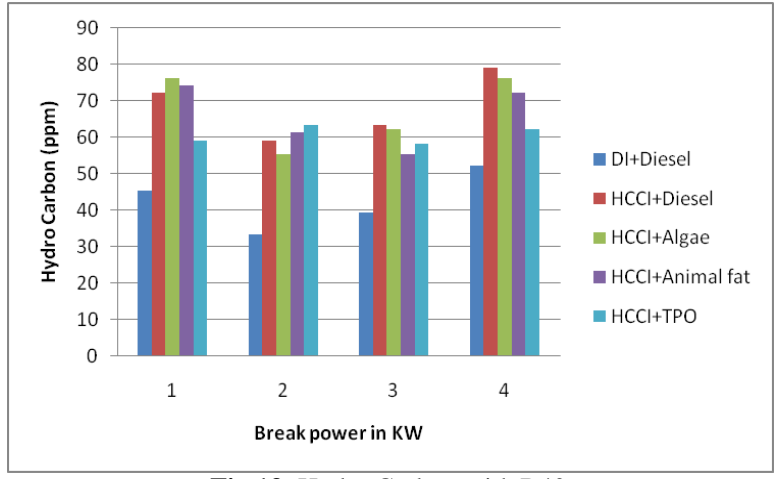

Fig.13: Hydro Carbon with B40

\section{Conclusion}

The performance and emissions of HCCI engine with different bio diesel fuels at constant speed $1500 \mathrm{rpm}$ was experimented. Change of the inlet temperature based on the performance of the fuels and blended bio diesel fuels are $20 \%$ and $40 \%$ with pure diesel.

The achieved break thermal efficiency of the HCCI -mode engine was less than the unmodified diesel engine. The optimum break power observed at temperature between $120-140^{\circ} \mathrm{C}$ operated under HCCI mode with micro algae oil for blends of $20 \%$. The performance of algae oil was nearly equal to the diesel fuel.

The specific fuel consumption of HCCI mode engine running with diesel fuels were less than bio diesel fuels. The fuel consumption of bio diesel fuels was continuously increased along with increase in their blends. Fuel consumption is optimum at B20 with variation of the temperature between $110^{\circ} \mathrm{C}$ to $130^{\circ} \mathrm{C}$ based on the fuels properties.

The HCCI engine has very low NOx emissions compared to conventional diesel engine due to lean air/fuel complete combustion inside the engine operated low temperature. Less amount of the oxide nitrogen was produced in HCCI mode engine. Micro algae oil produced less amount of NOx than other two bio diesel fuels. Increases in loads produced high NOx in the HCCI mode engine.

The HCCI engine produced more $\mathrm{CO}$ than the unmodified diesel engine. $\mathrm{CO}$ was increased when the engine was running with lean mixture and produced low temperature. As the HCCI engine was completely operated under lean mixture condition, high amount of $\mathrm{CO}$ was produced. The excess of oxygen present in the bio diesel fuels reacted with carbon dioxide and resulted to more carbon monoxide. The results indicate that the TPO was produced less amount $\mathrm{CO}$ than other two fuels. Micro algae oil consists of more amount of oxygen.

The HCCI produced very less amount of the smoke density than conventional diesel engine, the HCCI mode engine with micro algae oil produced less smoke density at all load conditions.

The HCCI engine was also produced more amount of HC than conventional diesel engine. HCCI engine was attained $83.5 \mathrm{ppm}$ and conventional diesel engine attained $51.2 \mathrm{ppm}$. The $\mathrm{HC}$ was reduced in HCCI engine under the bio diesel fuels operating conditions with minimum at $40 \%$ of the blends.

\section{References}

[1] Gray, A.W. and Ryan, T.W "Homogeneous Charge Compression Ignition of Diesel Fuel", Society of Automotive Engine, (1997), pp 971676. 
[2] Christensen, M and Johansson, B "Supercharged Homogeneous Charge Compression Ignition (HCCI) with Exhaust Gas Recirculation and Pilot Fuel", Society of Automotive Engine, (2000), pp 1835 .

[3] Zhao H, Li J, Ma T, Ladommatos N "Performance and analysis of a 4-stroke multi-cylinder gasoline engine with CAI combustion", SAE Tech Pap Ser., (2002) https://doi.org/10.4271/2002-010420

[4] Tsolakis, A. et al., "Application of exhaust gas fuel reforming in compression ignition engines fueled by diesel and biodiesel fuel mixtures", Energy Fuels, Vol.17, (2003), pp1464-73.

[5] Odaka, M et al., "Ignition and combustion control of diesel HCCI", Society of Automotive Engine, Vol.1, (2005), pp-2132

[6] Chisti,Y "Bio diesel from micro algae", bio technology advances,vol.25, (2007), pp.294-306.

[7] L. Xingcai, J. Libin, M. Junjun, H. Zhen, "Experimental study on the cycle-by-cycle variations of homogeneous charge compression ignition combustion using primary reference fuels and their mixtures", Proc. Inst. Mech. Eng. - Part D J. Automob. Eng. Vol.221 (2007), pp859-866

[8] Himabindu, $M$ et.al., " Effect of premixed charge of ethanol and exhaust gas recirculation on the performance and emission characteristics in an ethanol-diesel fueled HCDC engine - an experimental investigation", Society of Automotive Engine, (2008) pp2609

[9] Ramesh, S. Swami Nathan, J.M. Mallikarjuna, “An experimental study of the biogas-diesel HCCI mode of engine operation", Eng. Convers. Manage. Vol.51 (2010), pp 347-1353

[10] R.K. Maurya, A.K. Agarwal, "Experimental investigation on the effect of inlet air temperature and air-fuel ratio on cycle to cycle variation of HCCI combustion and performance parameter", Appl. Energy Vol.88, (2011), pp1153-1163

[11] Horng-Wen. Wu, "Reduction of smoke and nitrogen oxides of a partial HCCI engine using premixed gasoline and ethanol with air", Appl. Energy, Vol. 88, (2011), pp-3882-90

[12] Singh AP, Agarwal AK, "An experimental investigation of combustion, emissions and performance of a diesel fuelled HCCI engine", SAE Tech Pap Ser. 2012-28-0005, 2012 https://doi.org/10.4271/2012-28-0005

[13] D Ganesh and G Nagarajan, “Performance and Emission Analysis on Mixed-Mode Homogeneous Charge Compression Ignition (HCCI) Combustion of Biodiesel Fuel with External Mixture Formation", SAE international, 2011-01-2450, (2012), doi: 10.4271/ 2011-01-2450

[14] Chunhua Zhang, Han Wu, "Combustion characteristics and performance of a methanol fueled homogenous charge compression ignition (HCCI) engine", Energy Institute, (2015), pp 1-8. http://dx.doi.org/ 10.1016/ j.joei. 2015.03.005 1743-9671.

[15] A.Avinash, S.Natarajan,N.V.Mahalakshmi, "Lean homogeneous combustion of E-diesel using External mixture formation technique", Alexandria Engineering Journal, (2015) htpps://dx.doi.org/10.1016/j.aej . 2015. 02.2012.

[16] Akhilendra pratap singh, "Partially Homogeneous charge compression Ignition Engine development For low volatility fuels", ACS publications, (2017) doi:10.1021/acs.energy fuels.6b02832

[17] S. Gowthaman , A.P. Sathiyagnanam "The effect of exhaust gas recirculation on performance and emission characteristics of HCCI engine", International Journal of Ambient Energy, Vol 38 , issue 2, (2017) ,178-185, DOI: 10.1080/01430750. 2015. 1074616. 